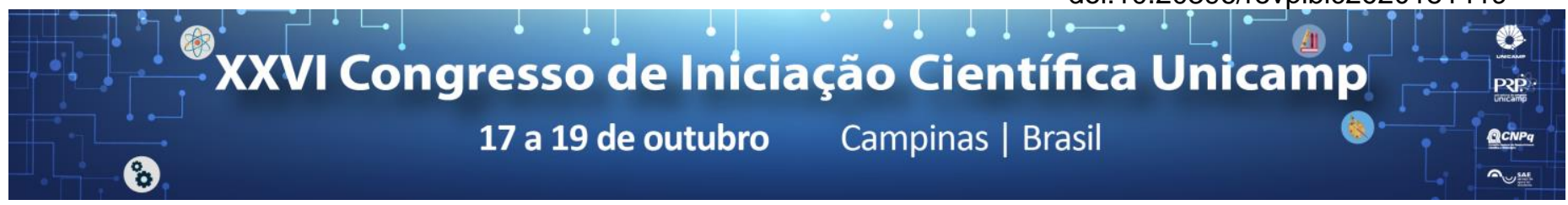

\title{
Lançador de Bolas de Tênis Sensoriado e Automatizado com Interface Bluetooth.
}

\author{
André A. O. Barbosa, Henrique F. Lopes, Luiz Ricardo Souza, Matheus M. Santos, Ricardo M. Zago, Fabio Kubo, \\ Renan A. Sterle e Fabiano Fruett
}

\section{Resumo}

Projetamos, fabricamos e testamos um robô lançador de bolas de tênis. Este robô permite controlar a força e o ângulo que a bola é lançada, possibilitando incluir efeitos como spin e slice. O deslocamento do robô pela quadra de tênis bem como o controle de todos seus motores é realizado atravéz de um dispositivo móvel conectado - sem fio - usando uma interface bluetooth.

\section{Palavras-chave:}

robô controlado remotamente, lançador de bolas, treinamento de tênis.

\section{Introdução}

O lançamento de bolas de tênis automatizado por uma máquina é uma ferramenta útil para o treinamento dos tenistas, sejam eles amadores ou profissionais. Teoricamente, uma máquina pode repetir uma sequência de lançamentos com grande precisão, incluindo ainda efeitos como spin (giro da bola sobre seu próprio eixo) de forma bem controlada. Há no mercado soluções que custam em média $R \$ 10.000,00$, porém não oferecem uma interface humano-máquina amigável e flexível. Este trabalho tem como objetivo apresentar um lançador de bolas de tênis construído com materiais de baixo custo que possa ser facilmente replicado em diferentes localidades e centros de treinamento. A interface com o usuário é totalmente baseada em um aplicativo compatível com a plataforma Android.

\section{Resultados e Discussão}

O robô lançador foi construído em uma base de MDF onde 5 motores foram montados. Os circuitos de comando dos motores foram projetados, fabricados e testados individualmente. A interface para controle destes motores foi realizada com um microcontrolador (ESP32) que dispunha de um rádio Bluetooth. Após os testes dos controles individuais, projetamos e montamos uma placa de circuito impresso unificando todos os circuitos e facilitando a montagem final.

Dois motores BLDC foram montados com polias de PVC que tinham suas velocidades controladas de forma independente pelo aplicativo. A bola de tênis passando entre as polias adquiria uma determinada aceleração sendo arremessada com força suficiente para o lado oposto da quadra. Os efeitos de slice e spin foram bem controlados pelo ajuste independente das velocidades das polias. Um motor de passo controlou o ângulo de lançamento. Esse motor recebia o sinal de um acelerômetro montado na haste vertical do lançador, o que permitiu ajustar o ângulo de partida da bola com relação ao solo.

Outros dois motores BLDC foram montados na base do robô lançador. Esses motores permitiram que o robô se deslocasse livremente pela quadra, avançando ou retrocedendo em direção a rede conforme a necessidade e dinâmica do treinamento.

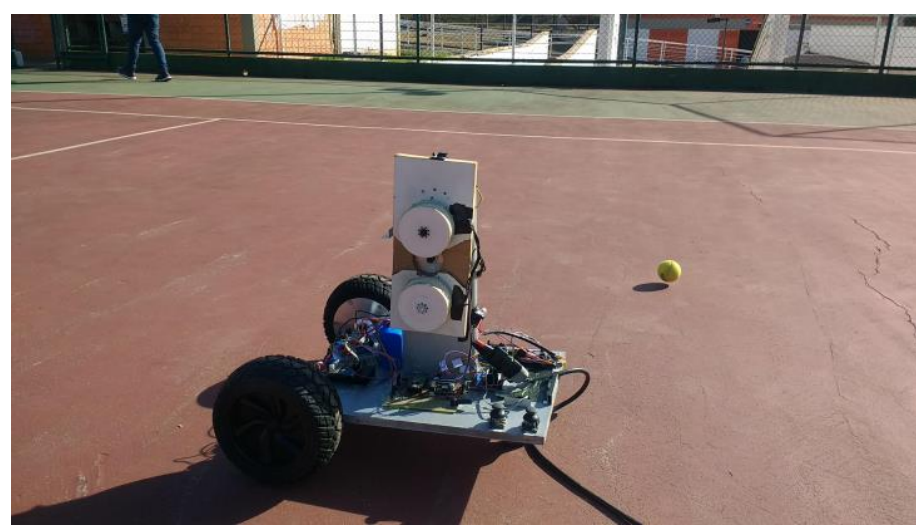

Figura 1.Lançador durante teste na quadra da Faculdade de Educação Física da Unicamp.

\section{Conclusões}

O projeto, a fabricação e o teste do primeiro protótipo de um robô lançador de bolas de tênis, controlado por um aplicativo embarcado em um dispositivo móvel (telefone celular ou tablete) com plataforma Android, foi concluído com sucesso. Implementamos 0 controle do lançador usando comunicação sem fio, tipo Bluetooth de baixa energia (BLE).

O protótipo desenvolvido atingiu seu objetivo e poderá ser facilmente replicado em outros centros esportivos e escolas de Tênis.

Este projeto foi concebido para ser facilmente replicado em outras localidades ou centros esportivos.

\section{Agradecimentos}

Agradecemos aos funcionários da FEEC, Carlos Giuliano e Audrey pela apoio na organização e montagem do robô. Agradecemos também a oficina de manutenção da FEEC por nos ajudar na confecção de algumas peças. A equipe do Laboratório de Sensores Microeletrônicos pelo apoio e companheirismo durante os nossos encontros semanais. 